\title{
PANOS BALOMENOS
}

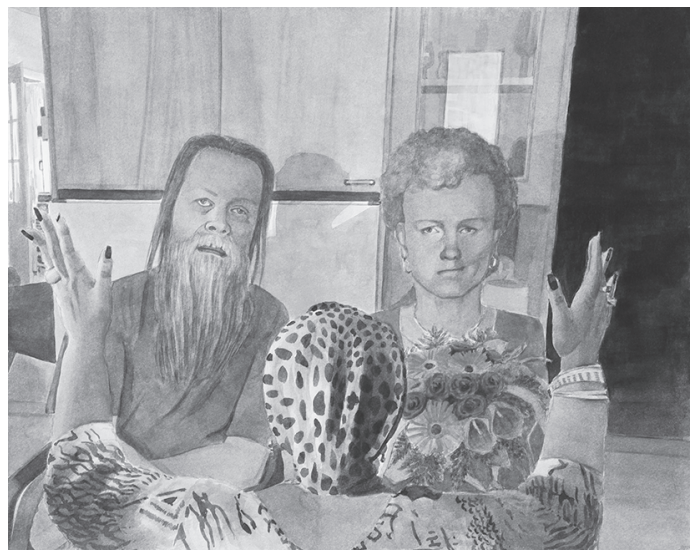

JOUNI JA RIITTA ESPOOSSA CESÁRIA ÉVORAN KANSSA, 2013.

Panos Balomenos (s.1976 Ateenassa) on opiskellut Milanon taideakatemiassa, Frankfurtin kuvataidekoulussa ja Helsingin kuvataideakatemiassa, josta hän valmistui maisteriksi vuonna 2005. Hän on osallistunut lukuisiin kansainvälisiin ja kotimaisiin näyttelyihin gallerioissa ja museoissa. Viimeisimpiä yksityisnäyttelyjä ovat järjestäneet Magito Studio, Helsinki (2015); TILA galleria, Helsinki (2011); FAIR, Kööpenhamina (2010); Galleria Sinne, Helsinki (2009); sekä Huuto Galleria, Helsinki (2008). Viimeisimpiä ryhmänäyttelyitä, joissa hän on ollut mukana, ovat XX Mäntän kuvataideviikot (2015); Body Memory, Valtion nykytaiteen museon nykytaiteen keskus, Thessaloniki (2014); Art Fair Suomi 2013, Helsinki; sekä Do not touch please, Brysseli (2010).

Panos Balomenoksen taideteokset koostuvat maalauksista, installaatioista ja puvuista. Niiden perimmäisenä tarkoituksena on performatiivisuus. Taiteessaan hän tarkastelee ihmistä muotokuvien kautta. Hänen numerossamme esittämänsä teokset ovat maalaussarjasta We are all made of stars (2011-2015). Hän on esitellyt sarjan tavoitteita seuraavasti:

1990-ja 2000-lukujen aikana maailman kehittynyt osa koki merkittävän taloudellisen kasvun, jota valitettavasti seurasi ennennäkemätön inhimillisyyden arvojen systemaattinen mureneminen. 2000-luvun loppuvuosina alkanut talouskriisi tuotti tämän prosessin huipentuman sekä sitä seuranneen jatkuvan heikentymisen.

Sekä nousu- että laskukaudella tietyt sosiaaliset ryhmät ovat yksinkertaisesti tuomittuja pysymään eristyneinä, koska niiltä puuttuu edustus mediassa. Ne eivät edusta Valtaa ja Rahaa; siksi ne pysyvät unohdettuina ja hylättyinä. Heihin kuuluvat huumeiden käyttäjät, yksinäiset sukulaisettomat ihmiset, köyhät, työttömät, henkisesti ja/tai fyysisesti vammaiset. Heitä ovat aikuisista riippuvaiset pienet lapset, homoseksuaaleihin ja muihin seksuaalivähemmistöihin kuuluvat ihmiset, prostituoidut, vanhat, rumat (mitä ikinä media tällä sanalla tarkoittaa), ylipainoiset, maahanmuuttajat, ulkomaalaiset sekä minkä tahansa määritelmän mukaiset vieraat. Heihin sisältyvät kaikenlaiset syrjintää kokevat etniset ryhmät.

We Are All Made Out Of Stars on yritys palauttaa voimaan ihmisarvo yhteiskuntiemme kaikilla eri tasoilla.

Panos Balomenos tiivistää taiteellisen työnsä tavoitteeksi esittää samalla kertaa puhdistuminen (katharsis) ja kritiikki. Hänen töistään välittyvä tunnelma on taiteilijan vastaus yhteiskunnalle, joka janoa valtaa, rahaa ja manipulaatiota. Kokoelma hänen töitään on nähtävissä hänen kotisivullaan http://www.panosbalomenos.com/. 